\title{
PNEUMONIA IN ANTIQUITY: A COMPARISON BETWEEN TWO PREANTIBIOTIC POPULATION SAMPLES FROM NORTHERN CHILE AND THE UNITED STATES
}

\author{
NEUMONÍA EN LA ANTIGÜEDAD: UNA COMPARACIÓN ENTRE DOS \\ MUESTRAS DE POBLACIONES PREANTIBIÓTICOS DEL NORTE DE CHILE Y \\ ESTADOS UNIDOS DE AMÉRICA
}

\author{
Arthur C. Aufderheide ${ }^{1}$ Lorentz E. Wittmers, Jr. ${ }^{1}$, and Bernardo Arriaza ${ }^{2}$
}

\begin{abstract}
This study is an effort to establish the contribution that pneumonia made to the causes of death in antiquity in the Andean coastal region of northern Chile. In addition, results were compared with modern populations from the 1920s, before effective therapy was widely available for this disease. A group of 197 spontaneously ("naturally") desiccated, mummified human remains from South America's western coast between about 19 to 21 degrees South Latitude (South Central Andes) was examined. The status of pathological, desiccated lungs was classified into the categories of normal and acute pneumonia on the basis of gross examination. The percentage of deaths (all ages) due to pneumonia in these mummies was $22.3 \%$ compared to the $10.1 \%(p=<0.01)$ for all ages for deaths in the United States in the 1920s during the preantibiotic era. However, infants (0-2 years) were especially vulnerable (45.9\% in antiquity, $13.7 \%$ in 1921). While the age-related pattern between the two populations was similar, results indicated that the percent of pneumonia deaths were substantially higher in antiquity than for the 1920s period, and that they were highest for infants less than 2 years of age, possibly due to immunological factors and environmental conditions.
\end{abstract}

Key words: Mummies, respiratory problems, epidemiology, Precolumbian Andes, USA.

En este ensayo se discute el papel de las neumonías como causa de muerte en la antigüedad en los Andes y se compara con los estudios de poblaciones modernas de la década de 1920 antes del desarrollo de un tratamiento efectivo para estas enfermedades. Para esto se examinaron los registros de autopsia de 197 cuerpos con momificación natural provenientes del lado occidental de Sudamérica entre los grados 19 a 21 de latitud sur (Área Centro Sur andina). Basado en los análisis morfoscópicos y la patología general, los pulmones momificados fueron clasificados como normal, con neumonía aguda, y recuperados (adherencias pleurales). El porcentaje de fallecidos (todas las edades) debido a las neumonías fue de 22,3\% comparado con un 10,1\% $(p=<0,01)$ para la misma categoría de muertes que ocurría en los Estados Unidos en la década de 1920, antes del uso de los antibióticos. Sin embargo, los infantes (0-2 años) eran los más vulnerables (45,9\% en la antigüedad y 13,7\% en 1921). Mientras que la distribución etaria fue similar en las dos poblaciones, los porcentajes de mortalidad por neumonía fueron significativamente más altos en la antigüedad que en la década de 1920 e independiente del periodo; la mayoría de los casos ocurrían en infantes menores de dos años, posiblemente debido a condiciones del desarrollo del sistema inmunológico y medioambientales.

Palabras claves: momias, problemas respiratorios, epidemiología, Andes precolombinos, USA.

One of the principal goals of the medical staff of the Paleobiology Laboratory in the Pathology Department at the University of Minnesota in Duluth (USA) is to identify the behavior of infectious diseases in ancient populations when people lived under conditions dramatically different from those of today (paleoepidemiology). Among the approaches that can be employed to measure the behavior of diseases in antiquity we have chosen to develop a quantitative inventory of causes of death. Information has been generated by dissection of mummified human remains and laboratory analysis of selected tissue samples. Consistent with this mission is the evaluation of bacterial pneumonia in antiquity. Abundant information is available about pneumonia in modern populations of developed, western countries before the 1920s (Heffron 1939). Effective therapy, including immune serum infusion and sulfanilamide chemotherapy did not become widely available until the 1930s

1 Paleobiology Laboratory, University of Minnesota Medical School Duluth, Duluth, MN 55812. aaufderh@d.umn.edu; lwittmer@d.umn.edu

2 Instituto de Alta Investigación, Departamento de Antropología, and Centro de Investigaciones del Hombre en el Desierto, Universidad de Tarapacá, Arica, Chile.barriaza@uta.cl 
(Musher 1998) and antibiotic therapy somewhat later. Therefore, we compared our ancient populations data with that available from the 1920s in the United States.

We identified the status of the lungs in 197 Andean mummies whose soft tissue preservation was sufficient to evaluate their gross anatomic pathologic status. Pneumonia-affected lungs were recognized by criteria described below.

\section{Pneumonia: The Disease}

The pneumococcus (Streptococcus pneumoniae) usually is transmitted from human to human by a pneumonia patient's coughing. This expels aerosolized pneumococcus bacilli-laden bronchial mucus droplets into the air. When these droplets are inhaled by a healthy person, the lung's defense mechanisms (principally the upward-flowing blanket of mucus lining the bronchi) trap the pneumococci before they reach the deeper lung tissue, and deliver them upward to the oral cavity. Here they join the normal flora of the oral cavity and may remain for 2 to 6 months without invading lung or other tissues. Pneumococci can be isolated from the oral cavity in 5 to $10 \%$ of healthy adults and four times that number in healthy children (Musher 1998). However, if such an individual with pneumococci in the oral cavity develops an upper respiratory infection of either viral or bacterial origin, the lung defenses are impaired (particularly the bronchial mucus blanket). Pneumococci present in the oral cavity may then progress downward into the temporarily defense-impaired lungs, initiating an invasive infection (pneumonia). The affected lung's air spaces (alveoli) become filled with pus, rendering breathing difficult. This manifests clinically as a highly febrile, prostrated patient. If the patient's immune system is mature and normal, it will respond briskly by generating a large number of antibodies that bring about the destruction of the pneumococci. The clinical response is an abrupt drop of body temperature to normal (the "crisis") and a feeling of well-being followed by complete recovery. An inadequate immune response leads to bacteremia (pneumococci in the blood stream), carrying the infection to all organs of the body, frequently resulting in a fatal outcome. Intermediate outcomes include complications such as lung abscess or spread into the thoracic cavity (empyema) (Musher 1998).

\section{Materials and Methods}

\section{The mummies}

The mummies were dissected by the paleopathologists and archaeologists at the Museo Arqueológico San Miguel of the Universidad de Tarapacá in Arica, Chile between the early 1970s to about 2004. These mummies had been exhumed from the coastal and low valley sites of South America's western coast between about 19 and 21 degrees South Latitude (Arriaza 1995; Arriaza et al. 2008; Muñoz 2004a, 2004b; Muñoz et al. 1993; Santoro 1982) (Figure 1). This is the location of the Atacama Desert where the hyperarid climate often converts bodies buried in its soil into spontaneously ("naturally") desiccated mummies. Fontana et al. (1983) had studied 108 of the 368 mummies excavated from this region in 1982 and found pneumonia to be the most common cause of death. This present study has extended the investigation to about 200 of the nearly 800 mummies now excavated, with emphasis on age-related differences. There were 785 readily available records or specimens of dissected mummies for our review. Other studies on these mummies have been reported elsewhere (Allison et al. 1982; Arriaza et al. 2005; Aufderheide 2003; Aufderheide et al. 2002; 2004; 2005; Guhl et al. 1999; Reinhard 1992; Santoro et al. 2005; Standen and Arriaza 1997). This group of mummies had been radiocarbon-dated between 2500 $\mathrm{BC}$ and $\mathrm{AD} 1500$. Anatomic dissection routinely included opening the thoracic and abdominal cavities, removing and examining the individual organs and recording the findings. Only mummies with records of sufficient preservation of soft tissues to permit evaluation of the lungs were included. A total of 197 such records or specimens $(25.1 \%$ of the total mummies dissected) constitute the database for our analysis (Table 1).

\section{Calculation of "percent pneumonia deaths"}

The Percent Pneumonia Deaths for ancient populations was expressed as a fraction of the acute pneumonia deaths among these 197 mummies. Modern USA (United States of America) 1921 census data (published by USA Bureau of Census in 1980) provided annual numbers of deaths of all causes by age and also listed the number of pneumonia deaths that composed part of that "Death Of All Causes" group. This permitted expression of 
Table 1. Data base of pneumonia infections and deaths for ancient and modern populations. Base de datos de infecciones por neumonía y defunciones en poblaciones antiguas y modernas.

\begin{tabular}{|c|c|c|c|c|c|c|}
\hline \multicolumn{4}{|c|}{ Ancient Arica population } & \multicolumn{3}{|c|}{ Modern USA population } \\
\hline $\begin{array}{l}\text { Age Group } \\
\text { (years) }\end{array}$ & \# of Mummies & $\begin{array}{l}\text { \# Deaths from } \\
\text { pneumonia }\end{array}$ & $\begin{array}{c}\% \\
\text { Pneumonia } \\
\text { deaths }^{1}\end{array}$ & $\begin{array}{c}\text { Deaths } \\
\text { All causes }\end{array}$ & $\begin{array}{c}\text { Deaths } \\
\text { from } \\
\text { pneumonia }\end{array}$ & $\begin{array}{c}\% \\
\text { Pneumonia } \\
\text { deaths }^{2}\end{array}$ \\
\hline $0-2$ & 37 & 17 & 45.9 & 188,918 & 25,886 & 13.7 \\
\hline $3-14$ & 47 & 11 & 23.4 & 76,033 & 7,336 & 9.7 \\
\hline $15-34$ & 50 & 6 & 12.0 & 134,620 & 10,029 & 7.4 \\
\hline $35-54$ & 63 & 10 & 15.9 & 188,093 & 16,113 & 8.6 \\
\hline Total & 197 & 44 & 22.3 & 587,664 & 59,364 & 10.1 \\
\hline
\end{tabular}

${ }^{1}$ For the ancient population the percent pneumonia deaths were calculated as the deaths from pneumonia divided by the total number of deaths multiplied by 100 .

${ }^{2}$ For the modern population the percent pneumonia deaths were calculated from the Bureau of Census Mortality Statistics (1921).

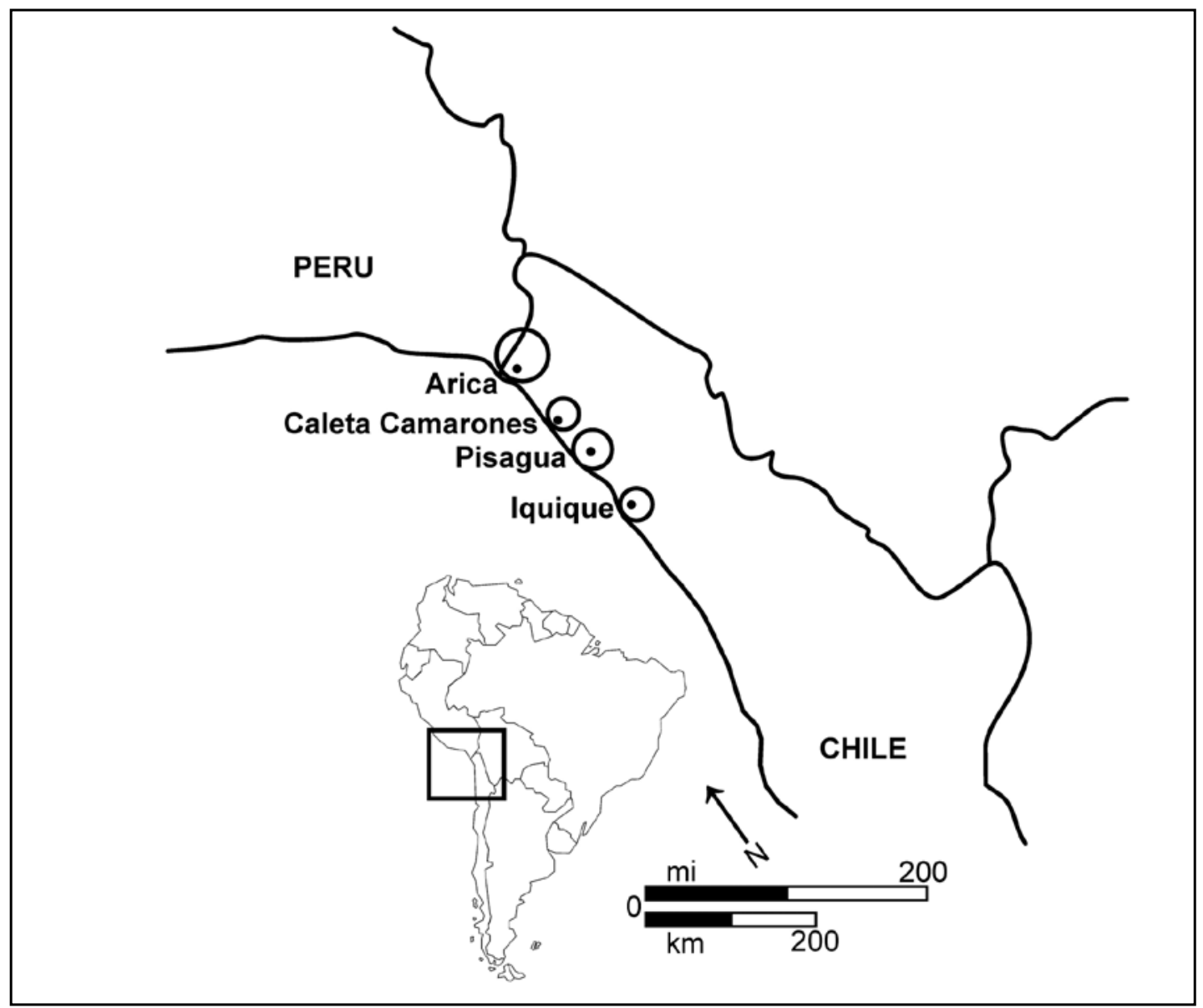

Figure 1. Sketch map indicating locations of coastal and low valley burial sites from which the mummies in this study were exhumed.

Mapa indicando los sitios de la costa y valle de donde se exhumaron las momias estudiadas. 
"Percent Pneumonia Deaths" as a percent fraction of the Deaths From All Causes group. For our Death From All Causes group for the ancient populations, we simply assigned to this category all mummies (197) with sufficient soft tissue preservation to evaluate the state of the lungs.

\section{Evaluation of lung structure}

Except for the major bronchial and vascular structure in the lung's hilum, normal lungs during life consist primarily of blood capillaries suspended in air to achieve the necessary gas exchange. After death the air diffuses out of the lungs and the capillaries' blood content drains and dries. In spontaneously desiccated mummies, a normal lung collapses after death, retracts medially and is converted into a flat, rectangular structure only a few millimeters thick, residing adjacent to the spine on each side, conforming to the curvature of the posterior thoracic cavity. If the mummified individual had developed pneumonia during life and died of it, the pus-filled, consolidated, affected lung remains thickened. It is commonly covered by white, crystalline material precipitated from electrolytes and powdered protein content of the pleural effusion that almost invariably accompanies such fatal pneumonia. The described changes in normal lungs and those of fatal pneumonia (thick, crystal-covered lungs) are dramatically different from each other. Each of these is easily recognized by gross observation alone (Aufderheide 2003:351, 438) (Figures 2, 3).

\section{Verifying gross pneumonia diagnoses}

In an effort to determine the validity of the diagnostic criteria, 519 autopsy records from a private, North American, community hospital were reviewed to identify pathologic conditions other than pneumonia that might be mistaken by gross examination alone for those due to pneumonia. Of these, 320 were from the interval of 1925 to1929 (prior to effective pneumonia therapy) and 199 from 1983 to 1985 . Ten cases of death due to large pulmonary infarcts were found that could have been mistaken for pneumonia on gross examination alone. Only two tumors simulated pneumonia grossly. Thus, a total of 12 of the 519 cases (2.3\%) could have led to a false diagnosis of pneumonia had they been judged only on the basis of gross examination. This suggests that the use of the described gross

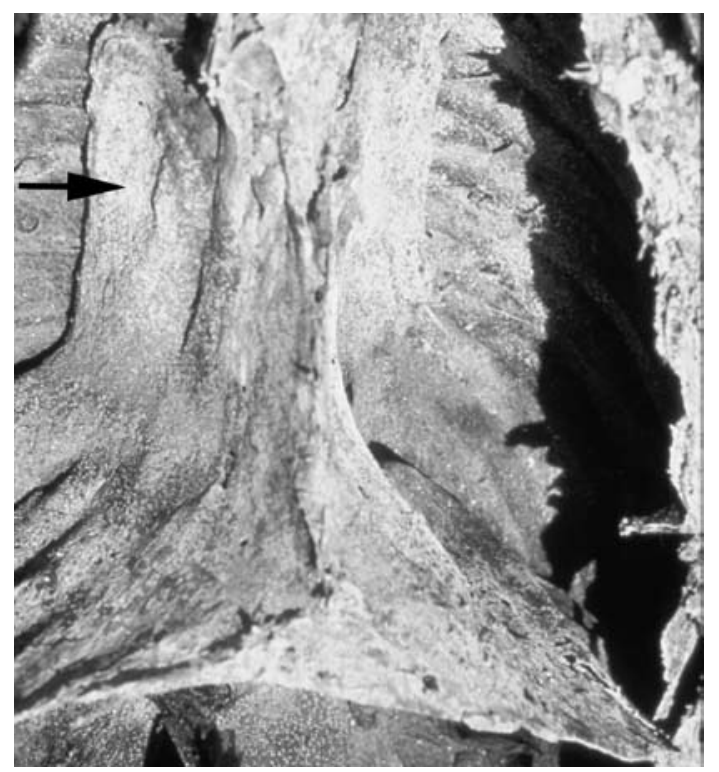

Figure 2. The interior of the thoracic cage of a 14 year-old boy. Arrow indicate the appearance and location of dried, normal lungs that collapse after death in a spontaneously desiccated body. The major bronchial and vascular structures of the hilum have become withdrawn into the mediastinal (midline) tissues, leaving only the flat, rectangular, thin $(2-4 \mathrm{~mm})$ membrane of the distal portion of the lungs.

Vista interna de la caja torácica de un niño de 14 años. La flecha indica la apariencia y lugar del pulmón normal, pero seco y colapsado después de la muerte, producto de la momificación natural del cuerpo. La estructura bronquial y vascular del hilio se ha recogido hacia la línea media del mediastino, dejando solo una membrana plana, rectangular y delgada en la parte distal del pulmón.

pathologic criteria would identify pneumonia with an expected accuracy of $97.7 \%$. For purposes of this study, the term "pneumonia" includes all forms, of which the most common are lobar pneumonia and bronchopneumonia.

\section{Sources of statistical data for the 1920s}

Values for modern USA populations (total population by age) were extracted from 1921 USA census tables (published by USA Bureau of Census, 1980) while the Deaths From All Causes were extracted from USA Mortality Statistics as were the Number of Pneumonia Deaths. Effective treatment with antibody-containing serum of patients recovered from lobar pneumococcic pneumonia was demonstrated as early as 1890 s (Klemperer and Klemperer 1891). In 1909 Neufeld and Händel reported that antigenic sites in pneumococci capsules differed among various pneumococcus strains. 


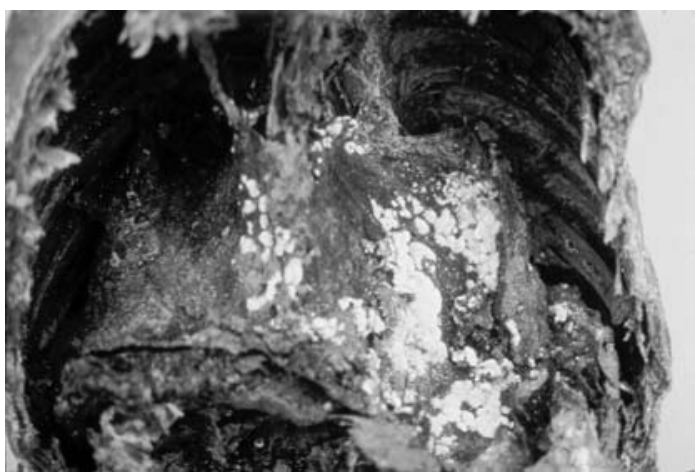

Figure 3. The left and right lower lobes are thickened (24 to $48 \mathrm{~mm}$ ) and covered with irregularly distributed white areas representing the protein and electrolyte crystals precipitated during the body's spontaneous desiccation interval after death from the inflammatory fluid effusion secondary to fatal acute pneumonia.

Los lóbulos derecho e izquierdo están engrosados $(24$ a $48 \mathrm{~mm})$ y cubiertos con un área blanca irregular, representando la proteína y cristales de electrolitos precipitados durante el intervalo de momificación natural del cuerpo, después de la muerte y debido a la inflamación y efusión de fluidos secundarios a la neumonía aguda y fatal.

Standardization of antisera based on these antigenic types finally made clinical studies available in the 1930s (Cole 1936). Sulfanilamide was used in the late 1930s (Heintzelman et al. 1937) but predictable success was unsatisfactory. Effective antibiotic therapy (penicillin) was not available until the 1940s. Hence, we chose national USA statistics from the 1920 s to reflect the "modern pretherapeutic period" with which to compare our data derived from our specimens of ancient populations.

\section{Age distribution justification}

Our description of pneumonia (see "Discussion" section) suggests that patterns of deaths due to pneumonia could be age-dependent. Given the development of the body's immune system and the changes in economic, social and environmental conditions as the individual ages, we have opted to divide the available population into four age groups: 0 to 2 years (infants), 3-14 years (children up to about puberty), 15 to 34 years (young adults) and more than 34 years (older adults).

\section{Results}

Table 1 and Figure 4 summarize the results of our studies. Table 1 also lists census data from the

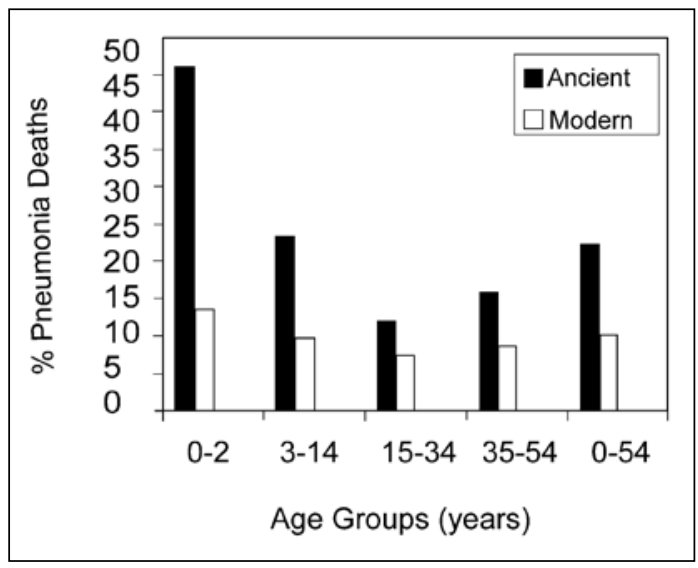

Figure 4 . The $\%$ pneumonia deaths for the ancient population was calculated as the number of deaths from pneumonia divided by the total number of deaths from all causes studied. For the modern population this value was taken as the death from pneumonia for 1920s divided by all deaths in that group. Note: the 0-54 age group is the overall value for the entire population studied.

El porcentaje de neumonía para la población antigua se calculó dividiendo el número de fallecidos por neumonía por el número total de momias estudiadas. Para la población moderna este valor corresponde a las muertes por neumonía de las décadas de 1920 dividido por el total de fallecidos en ese grupo. Nota: el rango de edad es de 0-54 años para toda la población estudiada.

1920s for the United States of America (USA Bureau of Census, 1921). The "Deaths From All Causes" and "Number of Acute Pneumonia Deaths" were obtained from USA census records. These values indicate that pneumonia was a major death risk not only in antiquity but even in the modern (1920s) pretherapeutic period. Furthermore, that risk was about twice as great in antiquity ( $22.3 \%$ vs. $10.1 \%)$ for all ages. In addition, a distinct and similar age pattern emerged for both ancient and modern time periods. Clearly, infants (0-2 years) were substantially more vulnerable than older age groups. Pneumonia accounted for $45.9 \%$ of all ancient infant deaths, a value almost four times greater than the equivalent modern infant group.

\section{Discussion}

\section{Pneumonia as the percent of all deaths}

Comparison of the data on our group of mummified bodies (including all ages) with that of a modern (1920s) United States population (Table 1; Figure 4) demonstrates that pneumonia accounted 
for about twice the fraction of deaths among the ancient population as compared with the modern (1921) population $\left(\mathrm{X}^{2}, \mathrm{p}<0.01\right)$. However, when specific age groups for both ancient and modern populations are selected and compared (Table 1), the differing effects of pneumonia on health become strikingly apparent. Both of these groups demonstrate that pneumonia is responsible for the largest fraction of deaths among infants (ages 0-2 years), a lesser fraction in children (ages 3-14) and stabilization of this variable in adults. Pre-Columbian infants were also affected by pneumonia 3.4 times more often than modern infants (Table 1).

The most probable factor generating the age-related feature in both populations is the well-known vulnerability of infants to bacterial infections. Indeed, infants can be viewed as similar to an immunocompromised population. While this age-related pattern is clearly evident in both ancient and modern populations, the quantitative aspects are substantially different. Pneumonia was responsible for nearly half of ancient infant deaths, a fraction almost fourfold greater than that seen in the 1920s United States population. In addition, variations ("serotypes") in the antigenic structure of the pneumococcic cell wall occur. Such serotypes have varying geographic as well as age distribution. More than 30 of such types are known, and are associated with varying pneumococcus virulence. It is conceivable that the pneumococcic types common in the studied South American region during antiquity were more virulent than those in North America in the 1920s. Alternatively, environmental factors including inadequate nutrition and arseniasis (Arriaza 2005) or other locally prevalent infections (Aufderheide et al. 2004) may have impaired the infants' immune response.

While absolute frequency values consistently are higher among the ancient populations, the age-related patterns are similar. This suggests that a factor common to all age groups may be responsible. Environmental factors would appear to be attractive candidates for this effect. In view of our knowledge about the pathogenesis of pneumonia (see the earlier "Pneumonia: The disease" section) conditions that would enhance inhalation of vaporized pneumococcus-containing sputum coughed up by an individual with acute pneumonia or any other infectious agent capable of causing upper respiratory infection would be expected to increase the frequency of the disease. Simple crowded shelters in antiquity could be responsible for such an effect. Thus such an environmental factor in addition to a serotype more virulent for infants common to the region of study conceivably could have brought about the patterns found in this study.

The Atacama valleys are narrow, and fertile land is scarce. Thus population density was low, compared to the Peruvian valleys, minimizing the risk of acquiring respiratory epidemics. However, we know in Arica coastal nucleation started very early ca. 7000 B.C. (Muñoz et al. 1993). Chinchorro shell middens, hearths and cemeteries reflect extensive occupation at the coast (Arriaza 1995; Santoro et al. 2005; Standen and Arriaza 1997). Also in the Azapa valley during the Early Intermediate Period mound burials become common and perhaps were used as ceremonial centers (Romero et al. 2004). Meanwhile during the agropastoral period people built villages and Pukaras reflecting centralized power, conflict and nucleation (Muñoz 2007; Muñoz and Chacama 2006). Thus, even though population density was low, semi-permanent (AZ115) or permanent (AZ75, AZ143) villages were bringing people together (Muñoz 2004b:306). Houses were small, made with perishable materials, often a few meters in diameter. They were central to planning daily domestic activities (Muñoz and Chacama 2006). Also Muñoz (2004a) said:

hasta fines del período Formativo, en los
valles, tal vez como consecuencia de una
mayor presencia de población, se habrían
empezado a construir asentamientos más
estables, aldeas, con la idea de albergar a
gente especializada como agricultores, arte-
sanos, alfareros, tejedores y orfebres.

Huts appear to be few but close to each other. Creation of villages opened the door to increased trade with highlanders as well as the spread of disease like pneumonia that thrives on crowding and aggregates of people. Moreover, evidence of Chagas disease, tuberculosis and intestinal parasites were also present in mummies and skeletons of these populations further testifying to crowded living conditions (Aufderheide et al. 2004; Reinhard 1992). Despite ancient Arica populations having fewer nucleation centers they had double the pneumonia rate than American modern samples, from the pre-antibiotic era or from the 1920s. We believe environmental factors were at play. For example, the Atacama 
Desert is full of minerals and fine dust (silica), a suspension commonly caused by winds or human activity. Tiny dust particles entering the air sacs may get trapped in the lungs producing scar tissue, reducing respiratory capacity and increasing the likelihood of respiratory problems such as silicosis and pneumonias. Also adding continuous exposure to smoke due to cooking in small huts, the burning of waste for those with an agropastoral subsistence, or exposure during firing of pottery, were some of the environmental and cultural factors predisposing ancient people to acquire pneumonias compared to the North American sample.

\section{Conclusions}

Pneumonia affecting the ancient populations of South America's western coast occurred in an epidemiological pattern similar to that of the 1920s in the United States prior to the availability of effective, specific therapy. This was characterized by a high (up to nearly 50\%) percentage of pneumonia deaths among infants dying from all causes in infancy. Thereafter such a percentage dropped rapidly during childhood and stabilized at a lower level in adulthood. The ancient studied populations had only rare deaths after age 54 years of age, because only a few lived to an age older than the middle fifties. Hence, members of our ancient groups died before the development of pneumonia as a terminal event that occurs so frequently in modern elderly persons dying of chronic illnesses such as cancer or cardiac disease. The progressive rise of pneumonia in the age periods following age 50 years in modern times was therefore not represented in this study. While the general age-related patterns of pneumonia were similar between ancient and modern populations, the quantitative effects were far more impressive in the ancient populations.

Maintenance of hydration and nutrition by intravenous fluid administration may have contributed to the lower mortality in the 1920s, but these medical aids seem unlikely to be the only or even principal factors in the lower values we found in the 1920s. Pneumococcus "serotypes" with greater virulence may have been more common in ancient South America. Our finding that half of ancient infant deaths in the studied area were caused by pneumonia makes a significant contribution to our efforts to establish the paleoepidemiology of fatal conditions in this geographic region (Aufderheide et al. 2004).

Acknowledgements: We wish to acknowledge the kindness of Marvin Allison, Ph.D. and the professional staff of the Departamento de Antropología at the Universidad de Tarapacá in Arica, Chile for the opportunity to review the departmental records and make the dissections related to this study and to Fondecyt Grant 1070575 for partial support. Many thanks to the anonymous reviewers who provided helpful comments.

\section{References Cited}

Allison, M., G. Focacci, M. Fouant, and M. Cebelin 1982 La sífilis ¿Una enfermedad Americana? Chungara 9:275-284.

Arriaza, B.

1995 Beyond Death, Chinchorro Mummies of Ancient Chile. Smithsonian Institution Press, Washington.

2005 Arseniasis as an environmental hypothetical explanation for the origin of the oldest artificial mummification practice in the world. Chungara Revista de Antropología Chilena 37:255-260.

Arriaza, B.T., L.L. Cartmell, C. Moragas, A.G. Nerlich, W. Salo, M. Madden, and A.C. Aufderheide

2008 The bioarchaeological value of human mummies without provenience. Chungara Revista de Antropología Chilena 40:55-65.

Arriaza, B., M. Doubrava, V. Standen, and H. Hass

2005 Differential mortuary treatment among the Andean Chinchorro fishers: Social inequalities or in situ regional cultural evolution? Current Anthropology 46:662-671.
Aufderheide, A.C

2003 The Scientific Study of Mummies. Cambridge University Press, Cambridge, U.K.

Aufderheide, A.C., S. Aturaliya, and G. Focacci

2002 Pulmonary disease in a sample of mummies from the AZ-75 cemetery in northern Chile's Azapa Valley. Chungara Revista de Antropología Chilena 34:253-263.

Aufderheide, A., W. Salo, M. Madden, J. Streitz, J. Buikstra, F. Guhl, B. Arriaza, C. Reiner, L. Wittmers, G. Fornaciari, and $\mathrm{M}$. Allison

2004 A 9,000 year record of Chagas Disease. Proceedings of the National Academy of Science of the USA 101(7):20342039.

Aufderheide, A.C., W. Salo, M. Madden, J. Streitz, K.Dittmar, J. Buikstra, B. Arriaza, and L. Wittmers.

2005 Aspects of ingestion transmission of Chagas disease identified in mummies and their coprolites. Chungara Revista de Antropología Chilena 37:85-90. 


\section{Cole, R.I.}

1936 Treatment of pneumonia. Annals of Internal Medicine 10(1):1-12.

Fontana, D., M. Allison, E., Gerszten, and B. Arriaza.

1983 Enfermedades respiratorias agudas en los habitantes Precolombinos del Norte Grande Chileno. Chungara 11:153-160.

Guhl, F., C. Jaramillo, G. Vallejo, R. Yockteng, F. Cardenas, G. Fornaciari, B. Arriaza, and A. Aufderheide

1999 Isolation of Trypanosoma cruzi DNA in 4,000-year-old mummified human tissue from northern Chile. American Journal of Physical Anthropology 108:401-407.

Heffron, R.

1939 Pneumonia. Harvard University Press, Cambridge, Massachusetts.

Heintzelman, J.H.L., P. Hadley, and R.R. Mellon

1937 Use of p-amino-benzenesulphonamide in Type 3 pneumococcus pneumonia. American Journal of Medical Sciences 193:759-763.

Klemperer, G., and F. Klemperer

1891 Versuche über Immunisirung und Heilung bei der Pneumokokkeninfection. Berlin Klinische Wochenschrift 28:869-875.

Muñoz, I.

2004a El período Formativo en los valles del norte de Chile y sur de Perú: nuevas evidencias y comentarios. Actas XV Congreso de Arqueología Chilena, Chungara Revista de Antropología Chilena, Tomo 1: 213-225.

2004b Estrategias de Organización Prehispánicas en Azapa: El Impacto de la Agricultura en un Valle del Desierto Costero del Pacífico. Ediciones Universidad de Tarapacá, Arica.

2007 Caillama: organización del espacio doméstico y áreas de actividad en un asentamiento prehispánico de altura, período Intermedio Tardío norte de Chile. Chungara Revista de Antropología Chilena 39:259-283.

Muñoz, I., and J. Chacama

2006 Complejidad Social en las Alturas de Arica: Territorio, Etnicidad y Vinculación con el Estado Inca. Ediciones Universidad de Tarapacá, Arica.
Muñoz, I., B. Arriaza, and A. Aufderheide, editors 1993 Acha-2 y los Orígenes del Poblamiento Humano en Arica. Ediciones Universidad de Tarapacá, Arica.

Musher, D.M.

1998 Pneumococcal Infections. In Harrison's Principles of Internal Medicine, edited by A.S. Fauci, E. Braunwald, K.J. Isselbacher, J.D. Wilson, J.B. Martin, D.L. Kasper, S.L. Hauser, and D.L. Lango, $14^{\text {th }}$ Edition, pp. 869-875. McGraw-Hill, New York.

Neufeld, F., and A. Händel

1909 Ueber herstellung und prüfung von antipneumokokkenserum and über die aussichten einer spezifischen berhandlung der pneumonie. Therapie 3:159-171.

Reinhard, K.

1992 Paleoparasitology as an interpretative tool in archaeology. American Antiquity 57:231-245.

Romero, A., C. Santoro, D. Valenzuela, J. Chacama, E. Rosello, and L. Piacenza

2004 Túmulos, ideología y paisaje de la fase Alto Ramírez del valle de Azapa. Chungara Revista de Antropología Chilena. Volumen Especial, Tomo 1:261-272.

Santoro, C.

1982 Formativo temprano del extremo norte de Chile. Chungara 8:33-62.

Santoro, C., B. Arriaza, V. Standen, and P. Marquet

2005 People of the coastal Atacama Desert. Living between sand dunes and waves of the Pacific Ocean. In Desert Peoples. Archaeological Perspectives, edited by P. Veth, M. Smith, and P. Hiscok, pp. 243-260. Blackwell Publishing, Australia.

Standen, V., and B. Arriaza

1997 Traumas en las poblaciones Chinchorro (costa norte de Chile), ¿violencia o situaciones accidentales? Chungara 29:1313-150.

United States Bureau of Census

1921 Mortality Statistics. U.S. Government Printing Office. Washington, D.C.

1980 General Population Characteristics, United States Summary, Life Tables for 1920. Government Printing Office, Washington, D.C. 